\title{
The Secret Dream World of Ángela Carballino in Unamuno's San Manuel Bueno, mártir
}

\author{
ALI SHEHZAD ZAIDI
}

\begin{abstract}
Critics have long held that Miguel de Unamuno's San Manuel Bueno, mártir concerns a village priest, Manuel Bueno, who suppresses his private doubts in order to preserve the happiness and simple faith of his parishioners. Notwithstanding critical tradition, a close look at the novella reveals that Manuel belongs to the secret dream world of its first-person narrator, Ángela Carballino. This paper peers into the hidden world of a protagonist who becomes a mother through her dreams.
\end{abstract}

Keywords: Miguel de Unamuno, San Manuel Bueno, mártir, oneiric, water imagery, mountain symbol

DOI: http://dx.doi.org/10.12697/IL.2013.18.1.16

Critics have long held that Miguel de Unamuno's San Manuel Bueno, mártir concerns a village priest, Manuel Bueno, who suppresses his private doubts in order to preserve the happiness and simple faith of his parishioners. Notwithstanding critical tradition, a close look at the novella reveals that Manuel belongs to the secret dream world of its first-person narrator, Ángela Carballino. This paper peers into the hidden world of a protagonist who becomes a mother through her dreams.

San Manuel was first published in 1931 in the magazine La novela de hoy and appeared two years later in a volume of short stories. Later editorial changes to the novella undermined Unamuno's artistic intent. John Butt notes that the numbering of the chapters turned a "single, apparently spontaneous, unplanned and necessarily disorganized recollection of Manuel by Ángela Carballino, into an ordered, calculated chronicle of events more closely resembling a conventional novel" (Butt 1981: 13). The Alianza Editorial edition of San Manuel, which went through twelve printings between 1966 and 1983, not only included the numbered chapters but also substituted the phrase "aquel varón patriarcal" for "aquel varón matriarcal" in the first paragraph (Unamuno 1983: 7). 
The Secret Dream World of Ángela Carballino in Unamuno's San Manuel Bueno, mártir

Using the narrative device of a discovered document (Ángela's memoir), Unamuno filters experience through two narrators: the author persona and Ángela who relates both her own and her brother's memories of Manuel. Robert L. Nicholas observes that the hierarchy of messengers, narrators, and readers in San Manuel draws the reader into the process of authorship (Nicholas 1987: 111). We wonder: are the narrators reliable? For instance, does Lázaro, an atheist, project his own unbelief onto Don Manuel?

The name Manuel, which means "God is with us" recalls that of Immanuel, the Messiah, foreseen in Isaiah, who is widely understood to be Christ (Butt 1981: 58). Ángela refers to him as 'san Manuel' throughout her narrative. The appellation is a pun, since 'sans' in French means 'without,' which would make Manuel's name ironic (Jurkevich 1991: 136). Ángela relates how Manuel echoes Mark 15, 34 which reads "My God, My God, why have You forsaken Me." Unamuno's narrative technique parallels the creation of myth in Christianity, particularly in regard to the life of Jesus, implicitly raising questions. Did Jesus believe what he preached? How true is life recounted secondhand? How true are our own lives?

The family name of the first person narrator, Ángela Carballino, is also the place name of a community founded at the foot of the twelfth-century monastery of Oseira in Galicia. Like Manuel, who regards the village as his monastery, Ángela dwells on Valverde from a strangely cloistered perspective. She opens her narrative with the news that the bishop of Renada has begun the process of canonizing Manuel:

\begin{abstract}
Ahora que el obispo de la diócesis de Renada, a la que pertenece esta mi querida aldea de Valverde de Lucerna, anda, a lo que se dice, promoviendo el proceso para la beatificación de nuestro Manuel, o, mejor, san Manuel Bueno, que fue en ésta párroco, quiero dejar aquí consignado, a modo de confesión y sólo Dios sabe, que no yo, con qué destino, todo lo que sé y recuerdo de aquel varón matriarcal que llenó toda la más entrañada vida de mi alma, que fue mi verdadero padre espiritual, el padre de mi espíritu, del mío, el de Ángela Carballino (Unamuno 1979: 95-96).
\end{abstract}

The place name 'Renada' suggests a place that is nothing, that subsists in the shadow of meaninglessness. ${ }^{1}$

Butt translates "Renada" as "absolutely nothing" or "Nowhere" (35). Other possible translations might be "emphatically nothing," "decidedly nothing," "non-existent," or even "nothing with a vengeance." 
ZAIDI

Valverde is a place beyond time or historical context (Gullón 1964: 334). According to Ángela, the village has no doubters or blasphemers, save for her brother Lázaro, who nonetheless comes to believe in the work of Manuel. More than a terrestrial locality, Valverde appears to be a mirror image of heaven. On his deathbed, Manuel tells the faithful: "Vivid en paz y contentos y esperando que todos nos veamos un día en la Valverde de Lucerna que hay allí, entre las estrellas de la noche que se reflejan en el lago, sobre la montaña" (Unamuno 1979: 139).

At first glance Manuel appears to be a surrogate father for Ángela, whose father died during her early childhood. However, the phrase "aquel varón matriarcal que llenó toda la más entrañada vida de mi alma” (Unamuno 1979: 95-96) suggests he in turn is her child, that she has conceived and borne him in her womb. The images of pregnancy that permeate Ángela's narrative ("Aquellos años pasaron como un sueño. La imagen de don Manuel iba creciendo en mí sin que yo de ello me diese cuenta" [Unamuno 1979: 114]) suggest that Manuel has been fashioned out of Ángela herself and is overcast with her personality.

Ángela's memories of her spiritual father appear vivid at first: "De nuestro don Manuel me acuerdo como si fuese cosa de ayer, siendo yo niña, a mis diez años, antes de que me llevaran al colegio de religiosas de la ciudad catedralicia" (Unamuno 1979: 96). However, Ángela's bewilderment towards the end of her narrative tells another story: “¿Es que sé algo?, ¿es que creo algo? ¿Es que esto que estoy aquí contando ha pasado y ha pasado tal y como lo cuento? ¿Es que pueden pasar estas cosas? ¿Es que todo esto es más que un sueño soñado dentro de otro sueño?" (Unamuno 1979: 147). The mutability of her memories suggests that they are deceptive and perhaps are indeed a thing of yesterday.

Those memories are conveyed through images of sleep and dreaming, as when Ángela describes Manuel giving communion to his congregation for the last time: "Me levanté sin fuerzas y como sonámbula. Y todo en torno me pareció un sueño" (Unamuno 1979: 134). Ángela's life, like her village, is altogether oneiric: "Pasé en el colegio unos cinco años; que ahora se me pierden como un sueño de madrugada en la lejanía del recuerdo, y a los quince volví a mi Valverde de Lucerna. Ya toda ella era don Manuel; don Manuel con el lago y con la montaña" (Unamuno 1979: 99).

The possessive adjective in the phrase "mi Valverde de Lucerna" denotes affection, but also suggests that the village, like don Manuel, is her creation. After finishing Catholic school at age sixteen, Ángela visits Manuel who greets her as "la hija de la Simona" (Unamuno 1979: 111). The name 'Simona' means something like "she who hears" (Kolatch 1967: 290), an apt name for a woman who hears imaginary voices. 
The Secret Dream World of Ángela Carballino in Unamuno's San Manuel Bueno, mártir

Ángela associates Manuel with the mountain, the lake, and the spiritualized collective life of her village: "Era alto, delgado, erguido, llevaba la cabeza como nuestra Peña del Buitre lleva su cresta, y había en sus ojos toda la hondura azul de nuestro lago" (97). In her mind, Manuel permeates the village through a spiritual geography:

Su maravilla era la voz, una voz divina, que hacía llorar. Cuando al oficiar en misa mayor o solemne entonaba el prefacio, estremecíase la iglesia y todos los que le oían sentíanse conmovidos en sus entrañas. Su canto, saliendo del templo, iba a quedarse dormido sobre el lago y al pie de la montaña. (Unamuno 1979: 101)

Ángela's words have an unmistakable maternal resonance.

The mountain represents the enduring and unchanging. Mircea Eliade notes that "a rock reveals itself to be sacred because its very existence is a hierophany: incompressible, invulnerable, it is that which man is not. It resists time; its reality is coupled with perenniality" (Eliade 2005: 4). The verb se queda reverberates in the final paragraph of the novella when the author persona expresses his hope that "todo se queda, como se quedan los lagos y las montañas y las santas almas sencillas asentadas más allá de la fe y de la desesperación” (Unamuno 1979: 149-150). The image of the clouds covering the summit of the mountain conveys our glimpse into the hidden inner lives of both don Manuel and Ángela: "Y no era un coro, sino una sola voz, una voz simple y unida, fundidas todas en una y haciendo como una montaña, cuya cumbre, perdida a las veces en nubes, era Manuel” (Unamuno 1979: 103).

Ángela relates how her brother Lázaro explains that "en el fondo del alma de nuestro don Manuel hay también sumergida, ahogada, una villa y que alguna vez se oyen sus campanadas" (Unamuno 1979: 120). The tolling bells seem to mark an eternal sadness and recall the legend of Valverde de Lucerna. Unamuno visited that village, on the lake of Sanabria, which was said to have been destroyed in a flood after it refused to give charity to Christ who was disguised as a beggar (Butt 1981: 14). The legend tells of human meanness, lack of charity, and rejection, all of which may have prompted Ángela's escape into the comfort of Valverde.

As Ángela tells it, the lake seems to beckon don Manuel into its depths. According to J. E. Cirlot, the lake 
equates all that is on a low level spatially with what is low in a spiritual, negative, destructive, and hence fatal, sense. The fact that water-symbolism is closely connected with the symbolism of the abyss serves to corroborate the fatal implications of the lake-symbol, for the part played by the liquid Element is to provide the transition between life and death, between the solid and the gaseous, the formal and the informal. At the same time, the lake - or, rather, its surface alone - holds the significance of a mirror, presenting an image of selfcontemplation, consciousness and revelation. (Cirlot 1962: 167-168)

Ángela describes how the falling snow, emblematic of both permanence and transience, remains on the mountain even as it disappears into the lake of death, the sea without waves. The snow evokes the white hair of both Don Manuel and Ángela, and hints at a chill realization. Towards the end of Ángela's narrative, the word 'nevando' reverberates as snow obliterates memory:

Y al escribir esto ahora, aquí, en mi vieja casa maternal, a mis más que cincuenta años, cuando empiezan a blanquear con mi cabeza mis recuerdos, está nevando, nevando sobre el lago, nevando sobre la montaña, nevando sobre las memorias de mi padre, el forastero; de mi madre, de mi hermano Lázaro, de mi pueblo, de mi san Manuel, y también sobre la memoria del pobre Blasillo, de mi san Blasillo, y que él me ampare desde el cielo. Y esta nieve borra esquinas y borra sombras, pues hasta de noche la nieve alumbra. (Unamuno 1979: 147)

Ángela conflates the village half-wit with Manuel when she refers to him as 'san Blasillo'. Blasillo's bathetic mimesis of Manuel and the simultaneous deaths of Manuel and Blasillo suggest that they are indistinguishable from one another and from their village. They belong to the same order of creation, to their creator Ángela, whose narrative confirms their unity.

Ángela relates how during a full moon Manuel told Lázaro: “iMira, el agua está rezando la letanía y ahora dice: Ianua caeli, ora pro nobis, puerta del cielo, ruega por nosotros!" (Unamuno 1979: 131). More than personifying water, these words reveal a sentient universe. Gary Fourstar expresses this intuition shared by indigenous peoples: "Water is alive, it hears our words, and responds to our speaking, to our thoughts, and to our words. The creator made nothing dead" (Gordon 2008). The moon incarnates divinity, prophecy, fertility, and madness (Neumann 1990: 211-212), dissolving boundaries between the animate and the inanimate. Cirlot makes the following observation: 
The Secret Dream World of Ángela Carballino in Unamuno's San Manuel Bueno, mártir

[a] significant aspect of the moon concerns its close association with the night (maternal, enveloping, unconscious and ambivalent because it is both protective and dangerous) and the pale quality of its light only half-illuminating objects. Because of this, the moon is associated with the imagination and the fancy as the intermediary realm between the self-denial of the spiritual life and the blazing sun of intuition. (Cirlot 1962: 206)

Like ripples of water passing over the lake like a north wind, a cold current of self-doubt sweeps over Manuel as he performs a ritual in which he does not believe: "Y llegó el día de su comunión, ante el pueblo todo, con el pueblo todo. Cuando llegó la vez a mi hermano pude ver que don Manuel, tan blanco como la nieve de enero en la montaña, y temblando como tiembla el lago cuando le hostiga el cierzo" (Unamuno 1979: 120). The chill wind undercuts his very reality. Manuel tells Ángela, “Como Moisés, he conocido al Señor, nuestro supremo ensueño, cara a cara, y ya sabes que dice la Escritura que el que le ve la cara a Dios, que el que le ve al sueño los ojos de la cara con que nos mira, se muere sin remedio y para siempre" (Unamuno 1979: 138). He senses that he is just a dream and fiction of Ángela.

According to Ricardo Gullón, "Todo en la aldea castellana es don Manuel; su presencia lo impregna y colma todo” (Gullón 1964: 338). This sentence would make more sense were we to substitute 'Ángela' for 'don Manuel.' Through the village Ángela projects her desire to cheat death and to remain. Consider Ángela's words regarding the legacy of her mentor:

¡Hay que vivir! Y él me enseñó a vivir, él nos enseñó a vivir, a sentir la vida, a sentir el sentido de la vida, a sumergirnos en el alma de la montaña, en el alma del lago, en el alma del pueblo de la aldea, a perdernos en ellas para quedar en ellas. Él me enseñó con su vida a perderme en la vida del pueblo de mi aldea, y no sentía yo más pasar las horas, y los días y los años, que no sentía pasar el agua del lago. Me parecía como si mi vida hubiese de ser siempre igual. No me sentía envejecer. No vivía yo ya en mí, sino que vivía en mi pueblo y mi pueblo vivía en mí. Yo quería decir lo que ellos, los míos, decían sin querer. Salía a la calle, que era la carretera, y como conocía a todos vivía en ellos y me olvidaba de mí, mientras que en Madrid, donde estuve alguna vez con mi hermano, como a nadie conocía, sentíame en terrible soledad y torturada por tantos desconocidos. (Unamuno 1979: 145-146)

Ángela’s insistent “¡Hay que vivir!” describes a psychic need, not an actuality. She is terrified and helpless outside her little world. 
ZAIDI

Critics have failed to see the many double meanings in San Manuel. When Ángela speaks of Lázaro and Manuel as collaborators and companions, she adds, "Los anudaba, además, el común secreto" (Unamuno 1979: 128). On the surface this sentence means that Lázaro knows that Manuel does not believe in afterlife or the immortality of the soul. However, their common secret might well be that both men are inventions and fictions of Ángela. Another example is when an anguished Manuel remains silent when Ángela asks him whether they will meet in the afterlife. He asks Ángela to absolve him, after which she reflects, "Me sentí como penetrada de un misterioso sacerdocio" (Unamuno 1979: 127). Critics overlook the possibility that Ángela is playing the roles of both herself and Manuel, and that those roles sometimes merge.

Ángela's name comes from the Greek word for angel or messenger (Butt 1981: 36). She portrays Manuel through the prism of the transformations in those who knew him, recalling the apostles who related the life of Christ in the New Testament. Like the mystics, Manuel lives on through the lives of others ("Sigamos, pues, Lázaro, suicidándonos en nuestra obra y en nuestro pueblo" [Unamuno 1979: 129]), and he secures an afterlife when Lázaro carries on his work. Manuel seeks to provide solace, not truth: "El contentamiento de vivir es lo primero de todo" (Unamuno 1979: 107). Lázaro concurs, for he tells Ángela, "hay que hacer que vivan de la ilusión” (Unamuno 1979: 142), words that recall Jean-Paul Sartre's observation that "Man cannot do without meaning, but he invents that meaning in an empty sky" (qtd. in Eliade 1982: 131).

Ángela carries out Manuel's labor of self-sacrifice and love. Like Manuel, her dream character, mentor, and son, Ángela seeks to escape loneliness and "toda la negrura de la sima del tedio de vivir" (129). She longs to become the $z a-$ gala on the hillside, whose song, Manuel tells us via Lázaro, is eternal presence:

Mira, parece como si hubiera acabado el tiempo, como si esa zagala hubiese estado ahí siempre, y como está, y cantando como está, y como si hubiera de seguir estando así siempre, como estuvo empezó mi conciencia, como estará cuando se me acabe. Esa zagala forma parte, con las rocas, las nubes, los árboles, las aguas, de la Naturaleza y no de la Historia (Unamuno 1979: 129-130).

Ángela projects her thoughts onto Manuel as when he explains to her that "no nací para ermitaño, para anacoreta; la soledad me mataría el alma, y en cuanto a un monasterio, mi monasterio es Valverde de Lucerna. Yo no debo vivir solo; yo no debo morir solo. Debo vivir para mi pueblo, morir para mi pueblo" (Unamuno 1979: 109). Ángela's description of Manuel's frenetic activity in the village might as well refer to her own fantastic story-telling: 
The Secret Dream World of Ángela Carballino in Unamuno's San Manuel Bueno, mártir

Con aquella su constante actividad, con aquel mezclarse en las tareas y en las diversiones de todos, parecía querer huir de sí mismo, querer huir de su soledad. "Le temo a la soledad", repetía. Mas aun así, de cuando en cuando se iba solo, orilla del lago, a las ruinas de aquella vieja abadía donde aún parecen reposar las almas de los piadosos cistercienses a quienes ha sepultado en el olvido la Historia (Unamuno 1979: 108-109).

Ángela conveys her act of self-hypnosis in the words of Manuel to Lázaro: "Opio..., opio... Opio, sí. Démosle opio, y que duerma y que sueñe. Yo mismo, con esta mi loca actividad, me estoy administrando opio” (Unamuno 1979: 133). The phrase "loca actividad" suggests madness. It is worth recalling that Unamuno suffered a nervous breakdown in 1925, the effects of which lasted another five years, a period which coincided with that of the writing of San Manuel. Just as Ángela speaks through Manuel, so does Unamuno speak through Ángela.

Ángela's story of the puppeteer is an act of self-revelation. A troupe of puppeteers arrives in the village. Although his wife is pregnant and gravely ill, the head puppeteer nonetheless entertains the crowd, assisted by his children. As he performs, the puppeteer sees his stricken wife led away by Manuel. When he finishes the show, the puppeteer discovers that his wife has died, and that Manuel had performed her last rites. He tells Manuel that he is a saint, upon which Manuel tells the puppeteer in front of the crowd,

El santo eres tú, honrado payaso; te vi trabajar, y comprendí que no sólo lo haces para dar pan a tus hijos, sino también para dar alegría a los de los otros, y yo te digo que tu mujer, la madre de tus hijos, a quien he despedido a Dios mientras trabajabas y alegrabas, descansa en el Señor, y que tú irás a juntarte con ella y que te paguen riendo los ángeles a los que haces reír en el cielo de contento. (Unamuno 1979: 108)

Ángela too is putting on a show; and Manuel is one of her puppets. Ángela must continue to spin her tale even though she, like the puppeteer's wife, is pregnant and deathly ill. Her story-telling is not a lie for it traces her own soul. Ángela is pregnant with the dream of Manuel, whose words to Ángela take on a new meaning when seen in this light: "Sí, al fin se cura el sueño..., y al fin se cura la vida..., al fin se acaba la cruz del nacimiento... Y como dijo Calderón, el hacer bien, y el engañar bien, ni aun en sueños se pierde" (Unamuno 1979: 136). Indeed, for nearly a century Unamuno has deceived the critics through the theatrics of Ángela, who orchestrates this key scene: 
Y cuando en el sermón de Viernes Santo clamaba aquello de “¡Dios mío, Dios mío!, ¿por qué me has abandonado?”, pasaba por el pueblo todo un temblor hondo como por sobre las aguas del lago en días de cierzo de hostigo. Y era como si oyesen a Nuestro Señor Jesucristo mismo, como si la voz brotara de aquel viejo crucifijo a cuyos pies tantas generaciones de madres habían depositado sus congojas. Como que una vez, al oírlo su madre, la de don Manuel, no pudo contenerse, y desde el suelo del templo, en que se sentaba, gritó: “¡Hijo mío!”. Y fue un chaparrón de lágrimas entre todos. Creeríase que el grito maternal había brotado de la boca entreabierta de aquella Dolorosa - el corazón traspasado por siete espadas - que había en una de las capillas del templo. Luego Blasillo el tonto iba repitiendo en tono patético por las callejas y como en eco, el “¡Dios mío, Dios míos!, ¿porqué me has abandonado?”, y de tal manera que al oírselo se les saltaban a todos las lágrimas, con gran regocijo del bobo por su triunfo imitativo (Unamuno 1979: 101-102).

Ángela does not name Manuel's mother, for she herself is the mother. Ángela is the author of Blasillo's "triunfo imitativo" which resembles that of a puppeteer.

Ángela's memoirs conclude with a line break, after which the narrative

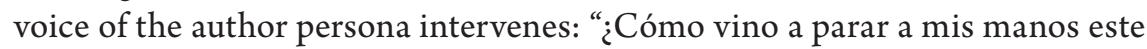
documento, esta memoria de Ángela Carballino? He aquí algo, lector, algo que debo guardar en secreto" (Unamuno 1979: 148). He cites an epistle from St. Jude to the effect that only God ought to judge the Devil. We recall that Ángela often wonders whether she is possessed. The author persona appears to ask us to refrain from judgment when he writes, "Y el que quiera entender que entienda" (Unamuno 1979: 149).

Critics have yet to speculate how the author persona might have found Ángela's narrative. They have yet to fully explore the imagery of this richly ambiguous novella. To which truth does Manuel allude when he says, "¿La verdad? La verdad, Lázaro, es acaso algo terrible, algo intolerable, algo mortal; la gente sencilla no podría vivir con ella" (Unamuno 1979: 122-123)? Donald L. Shaw, whose focus on Manuel typifies much of the criticism on the novella, provides this facile generalization: "It is the truth of reason, the realization that death is the end and belief in transcendental values an illusion. All the Generation of 1898 shared this vision of the truth" (Shaw 1975: 62).

If this is so, how does one explain Unamuno's devout Catholic practices? As Butt observes, Unamuno "always wore a crucifix, attended mass frequently, insisted on saying the family rosary every day, regularly went into retreat in monasteries and read from the Gospels (in Greek) daily” (Butt 1981: 49). We might consider Unamuno's faith in light of Bunuel's remark, "Soy ateo gracias a Dios" (qtd. in Santander 2002) which conveys a sense of paradox and 
The Secret Dream World of Ángela Carballino in Unamuno's San Manuel Bueno, mártir

contradictory feelings. In his Diario íntimo Unamuno wonders, "Pero ¿no tendré tal vez una fe en el sacramento, velada aún para mí y que al recibirlo se me revele?" (qtd. in Jurkevich 1991: 141).

Contrary to Shaw's assertion, truth in San Manuel is a lonely woman in her fifties lying in a loveless bed. Shaw follows the pattern of critics who focus on Manuel to the almost complete neglect of Ángela:

The flower in Don Manuel's breviary stands for his lost faith; hence the cross and date. The nut-tree from which he cuts planks for his coffin represents his childhood faith. Hence the strange adjective 'matriarcal' applied to it: Unamuno identified spiritual comfort with return to his mother's arms (Shaw 1975: 63-64).

Shaw's interpretations of the images of the flower and the nogal are unconvincing. Does loss of faith arrive all at once, on a certain date, as Shaw would have it, or does it come gradually, like erosion? Might not the wilted flower represent instead unrequited and unfulfilled love, or the twisted effects of the sexual repression induced by the Catholic Church? Shaw relates the nut-tree to childhood faith without explanation, as if such a connection were transcendentally true.

If the ubiquitous adjective 'matriarcal' seems strange to Shaw, it is because he overlooks Ángela and her desire to be a mother. The leaves of the nogal, or walnut tree, were traditionally used in Spain to induce abortions or to sterilize women (Nogal). Ángela ceases to be a mother when Manuel dies. Hence his burial in a coffin made from the planks of the nogal. This conforms to the conception of birth and death that is expressed by a character in Unamuno's Amor y pedagogía: "así como nuestro morir es un des-nacer, nuestro nacer es un desmorir" (qtd. in Olson 1984: 33).

The author persona states in the final lines of San Manuel that what Ángela relates has not really happened, suggesting that it is all a dream:

bien sé que en lo que se cuenta en este relato no pasa nada; mas espero que sea porque en ello todo se queda, como se quedan los lagos y las montañas y las santas almas sencillas asentadas más allá de la fe y de la desesperación, que en ellos, en los lagos y las montañas, fuera de la historia, en divina novela, se cobijaron (Unamuno 1979: 149-150). 
The very last word of the novella refers to sleep, with the lake, the mountains, and Ángela, all tucked in together under the bedcovers where Ángela dreams her final dream. And yet, according to the author persona, we must not yet doubt the reality of dreams: "De la realidad de este san Manuel Bueno, mártir, tal como me lo ha revelado su discípula e hija espiritual Ángela Carballino, de esta realidad no se me ocurre dudar. Creo en ella más que creía el mismo santo; creo en ella más que creo en mi propia realidad" (Unamuno 1979: 148). In their close attention to Manuel and comparative neglect of Ángela, the critics demonstrate the truth and power of fiction.

\author{
Ali Shehzad Zaidi \\ zaidia@canton.edu \\ Department of Humanities \\ 524 Faculty Office Building \\ SUNY Canton \\ 34 Cornell Drive \\ Canton New York 13617 \\ USA
}

\title{
References
}

Butt, J. 1981. Miguel de Unamuno: San Manuel Bueno, Mártir. London: Grant \& Cutler. Cirlot, J. E. 1962. A Dictionary of Symbols. [J. Sage, transl.] London: Routledge \& Kegan Paul.

Eliade, M. 2005 [1954]. The Myth of the Eternal Return. [W. R. Trask, transl.] Princeton: Princeton University Press.

Eliade, M. 1982. Ordeal by Labyrinth. [D. Coltman, transl.] Chicago: University of Chicago Press.

Gordon, A. 2008. Water is Alive, It Hears Our Words. - Inter Press Service, 14.06, http://www.commondreams.org/archive/2008/06/14/9628 (05.08.2012).

Gullón, R. 1964. Autobiografías de Unamuno. Madrid: Editorial Gredos.

Jurkevich, G. 1991. The Elusive Self. Archetypal Approaches to the Novels of Miguel de Unamuno. Columbia: University of Missouri.

Kolatch, A. J. 1967. The Name Dictionary. New York: Jonathan David.

Neumann, E. 1990. On the Moon and Matriarchal Consciousness. - P. Berry, ed., Fathers and Mothers. Dallas: Spring Publications, 210-230.

Nicholas, R. L. 1987. Unamuno, narrador. Madrid: Editorial Castalia.

Nogal. Plantas Mágicas. - Espíritu Gaia, http://www.espiritugaia.com/NogalMag. htm (05.08.2012).

Olson, P. R. Unamuno: Niebla. London: Grant and Cutler, 1984. 
The Secret Dream World of Ángela Carballino in Unamuno's San Manuel Bueno, mártir

Santander, H. N. 2002. Luis Buñuel, director existencial. - Espéculo, 20, http://www. ucm.es/info/especulo/numero20/bunuel.html (26.07.2012).

Shaw, D. L. 1975. The Generation of 1898 in Spain. New York: Barnes and Noble.

Unamuno, M. de. 1979 [1933]. San Manuel Bueno, mártir. [M. Valdés, ed.] Madrid: Cátedra.

Unamuno, M. de. 1983 [1933]. San Manuel Bueno, mártir. Como se hace una novela. Madrid: Alianza Editorial. 